\title{
Present and Future of the British Schools, Institutes and Societies Abroad
}

\author{
Bill Finlayson \\ Director, Council for British Research in the Levant (CBRL)
}

The British Schools, Institutes and Societies comprise a group which collectively receives a substantial proportion of the British Academy's research funding but whose current work is perhaps less well-known than it should be within the UK. The scale of the Academy grants leads properly to concern that the funding represents good value for money. In all assessments so far the answer has been positive, but some negative opinions have been expressed. As some of these are based on academic urban myths or past situations that no longer apply, I appreciate this opportunity to provide a basic account of where we are now. The invitation to write this paper referred to the British Schools abroad, a term in itself a little out of date, and it is impossible to discuss these without referring to other, similar bodies. This paper is written for an archaeological audience and therefore concentrates on this aspect of the Schools' work, but it should be stressed at the outset that archaeology is only one area of interest.

There are 11 learned societies directly supported by the British Academy to conduct research overseas (see Table 1, which provides abbreviations). The fact that the Academy grant is divided between 11 institutions (in fact 12, as about $8 \%$ of the grant awarded to Schools and Institutes goes to the Council for British Archaeology) immediately puts some perspective on the scale of the funding ( $£ 3478500$ in 2005/2006). They are a diverse collection of bodies across the world, established at different times and with differing briefs. The Academy started providing continuous annual funding to the Schools abroad in 1950; previously they had relied mostly on their endowments and subscriptions, but after the Second World War their endowments declined in value. They are often divided into those with overseas bases (the Schools and Institutes), and the Societies who operate with a smaller infrastructure, but even this is a somewhat artificial distinction: the EES, for example, has an office in Cairo. The British Academy refers to all 11 as 'institutions', and that usage will be followed here.

This paper is not an account of the history of the institutions, except in so far as past practices and establishments affect the present. The processes of closure, transformation and merger that are clear from Table 1 are one illustration that these institutions, often regarded as rather static and ancient, are constantly evolving like any other organisations. This paper can only represent a snapshot of current circumstances.

The British Academy is the main sponsor for all these institutions, and indeed was instrumental in the establishment of most of them. In 1994/1995 the British Academy conducted a review of all the institutions (Wilson 1996). This document has for a while served as a baseline for discussions, although it is becoming rather dated and no longer matches the existing situation, either within the institutions or in the UK. The Humani-

Papers from the Institute of Archaeology 16 (2005): 1-9 
ties Research Board (HRB), for example, has been replaced by the Arts and Humanities Research Board (AHRB), and now by the Arts and Humanities Research Council (AHRC), with consequent changes for the Academy, including the shift from funding for the Academy from the Department for Education and Skills (DfES) to the Office of Science and Technology (OST) within the Department of Trade and Industry (DTI). This has led to a recent review of research funding by the Academy, both for the institutions and for other external applications for Academy funding to conduct research within the geographical and subject areas covered by the institutions. In between these wide-ranging reviews the institutions have to apply for funding on an annual basis, and are subject to periodic review on-site.

- The British Institute at Ankara, BIAA (founded 1948)

- The British School at Athens, BSA (founded 1886)

- The British Institute in Eastern Africa, BIEA (founded 1959)

- The British School of Archaeology in Iraq, BSAI (founded 1932)

- The British Institute of Persian Studies, BIPS (founded 1961)

- The British School at Rome, BSR (founded 1901)

- The Council for British Research in the Levant, CBRL (founded 1998 on the merger of the British School of Archaeology in Jerusalem, BSAJ, founded in 1919, and the British Institute in Amman for Archaeology and History, BIAAH, founded in 1978)

- The Egypt Exploration Society, EES (founded 1882 as the Egyptian Exploration Fund)

- The Society for Libyan Studies, SLS (founded 1969)

- The Society for South Asian Studies (founded 1983, successor to the Society for Afghan Studies, founded in 1972)

- The Committee for South East Asian Studies (founded 1986, successor to the British Institute in South-East Asia, founded in 1975)

Table 1. Institutions supported by the British Academy to conduct research overseas.

The geographical distribution of the institutions (and perhaps even more the distribution of funding within them) is a clear reflection of a combination of traditional and contemporary understandings of our cultural, religious and scientific roots (predominantly the older institutions) and British Imperial and Commonwealth connections (the more recently established societies). While there are many other parts of the world clearly worthy of research, the historical reasons for the foci of the institutions are still with us today. Recent debates on the significance of the cultural heritage of Iraq, the lack of understanding of the Arab Islamic world, the importance of shared European heritage and the multicultural roots of modern UK society make this obvious, especially given the current wider disciplinary coverage of the institutions.

The extent of variation between the institutions means that I can write most effectively from a CBRL perspective, and the detail of the other institutions will not always be the 
same. "Few general statements about the Institutes and Societies are equally true of each, and what particularly marks out one is hardly ever characteristic of all" (Wilson 1996: A59).

\section{Academic Scope}

In the 1996 report the institutions were referred to as "the forward posts of British Academe" (Wilson 1996: A113). While it may not be entirely clear what this means, it certainly suggests a wide-ranging role in terms of academic subjects, a need to be at the forward edge of research, and to be out there in terms of both contacts with overseas researchers and the fields of study. In the past, some institutions have focused more on their research facilitation role, but all now pursue research through their staff and institutional projects much more aggressively.

It is often assumed that the institutions are entirely archaeological in their interests. The British Academy website states that disciplinary coverage is greater than this, and notes that the significance of archaeology is a "perception" held by the institutions and their scholarly constituencies (British Academy 2005). Similarly, archaeology was the only research subject to be given extensive coverage in the 1996 report. There is no doubt that archaeology is a great strength for many of the institutions, and a subject in which many claim to be centres of excellence. Yet all institutions now cover a much wider range of subjects, and indeed all were always broader than general perception, or indeed their titles indicated. Of the current institutions several still list archaeology as their principal activity. The EES refers to itself as a leading "archaeological organisation" (EES 2005); the aims of the BSAI are "to encourage, support and undertake research into the archaeology (and cognate subjects) of Iraq, and the neighbouring countries, from the earliest times to c.AD 1700" (BSAI 2005); the BIAA states that it covers the arts, humanities and social sciences, but maintains "a centre of excellence in Ankara focused on the archaeology and related subjects of Turkey" (BIAA 2005); and while the BSA (2005) and the BIPS (2005) state that they engage in a broad spectrum of research, the projects listed on their website are all archaeological or related. The BSR is the clearest example of an institution that was established with a broad remit, and which strongly maintains that remit, although again the principal projects visible on the website appear archaeological (BSR 2005). Examination of scholarship/fellowship programmes gives a clearer indication of the wider disciplinary breadth. The former BSAJ was unusual in that it was established through an initiative by the British Academy and the Palestine Exploration Fund, with the support of the Foreign Office, specifically as an archaeological excavating body but also to provide training for the Antiquities Service in Palestine (and Transjordan, as it turned out (Gibson 1999)). Its successor, the CBRL, currently employs only one archaeologist out of six research active staff.

One of the great archaeological strengths of the institutions has been in field survey, with major survey projects such as research in Wadi Faynan in Jordan (which involved teams and staff from 15 UK universities, building in part on previous expertise gained in Libya under the auspices of the SLS), studying prehistoric settlement, the transition to sedentism, water management and agriculture, the changing natural environment and the effects of pollution (ancient and modern) from copper mining and processing (cf. 
Barker et al. 2000; McQuitty 1998; Mithen et al. 2000). The Tiber Valley Project in Italy had a similarly high involvement from British universities (11 and the British $\mathrm{Mu}$ seum) and multi-disciplinary nature (Patterson 2004). Perhaps surprisingly for those unfamiliar with the EES, a substantial part of their research is survey-based. A significant aspect of all these surveys has been their multi-disciplinary character, involving archaeologists, geomorphologists, geologists, anthropologists and architects.

One of the problems facing the institutions in realising their generally shared plans to increase academic breadth is that much of their infrastructure (libraries, laboratories and field equipment/bases), together with their formal links to local government departments and their role in archaeological permit applications, is archaeological in nature. None of the institutions proposes to destroy this important and thriving area of research, or indeed to weaken the core strengths of their libraries. The problem is that within current resource models it is difficult to increase some of the resources available for other disciplines without reducing others.

Some of the institutions play an important part in obtaining permits for archaeological fieldwork. The situation is most clear-cut in Athens, where the number of archaeological permits available is limited, and applications must be made through the School, but many countries require some involvement by the relevant British institution in the permit application process, including the provision of a fixed local contact address, laboratories and stores, all of which may be requirements for the permit. Other facilities offered by the Schools and Institutes may not be statutory requirements but can make an enormous difference to the success of a project in terms of its commencement, fieldwork and post-excavation analysis. These include reference collections, libraries, map and aerial photograph collections, drawing facilities, computing facilities, fieldwork equipment and the provision of a long-term base for multi-year projects. These facilities are not marginal to projects, nor are they restricted to archaeologists. The fieldwork equipment is frequently used by researchers from other disciplines, such as geographers and geologists, while such facilities as the libraries and computers are used by all.

Libraries are a particularly important feature of many of the institutions. It is not only those with overseas establishments that have libraries; the EES for example has an important library in the UK. Libraries vary enormously in size, from the libraries in Rome and Athens, which can be the main reason for UK-based academics to travel to the institutions, to libraries such as that held by the school in Iraq, which was mostly a reference collection for excavators. In between lie the libraries in Ankara, Amman and Jerusalem. These do not attempt to compete with large university libraries or copyright libraries, but provide important services, several of which are held in common with the larger libraries of Athens and Rome. One of these is to provide reference material while people (both staff employed by the institutions and visiting project staff) are in the country. This is a vital facility, especially as much post-excavation work has to be conducted in the country where excavation has been undertaken.

The institutions also play an important role in conducting regional research. The CBRL and BIEA both have physical bases in their areas, but operate in a number of countries 
within their regions, a pattern increasingly followed by the BIAA. Recently, the various institutions around the Mediterranean have established a working group to begin to formally encourage and develop regional research agendas in collaboration. Of these, two are overtly archaeological: the development of a cross-Mediterranean ceramic petrology to investigate large-scale patterns of trade and exchange and the transfer of technologies and people; and the synthesis of field-survey results to address broad historical questions of changing patterns of demography, settlement, use of landscape and the impact of urban development. A third regional research topic, examining modern and historical concepts of East and West, will include an archaeological component.

A key item for all research active staff is to make sure that they are engaged in the world of UK academia, and that their institutions are also well connected to this world. This has included appointing directors seconded from UK universities, ensuring that where research staff are not seconded they develop formal links to UK universities (such as honorary fellowships), providing sabbatical leave to be spent in UK universities, and helping to develop junior staff towards returning to the UK to undertake PhDs. The committees that oversee the operations of the institutions are largely made up of UK academics, who also provide an important link. All staff are very aware of the Research Assessment Exercise (RAE), and the importance of ensuring that they are producing research and publications that are appropriate for a UK higher education (HE) sector dominated by this exercise. All institutional and affiliated projects are inevitably judged by this yardstick, both when initially established and on their achievements. This has had the effect of encouraging shorter projects with more tightly defined research goals and publication plans, which has undoubtedly improved publication records and focus, but has been less helpful for long-term research projects and has led to a significant decline in the excavation of substantial tell sites.

An important role that several institutions have adopted, similar to that undertaken in recent years by government agencies in the UK, has been to address excavation publication backlogs. This has been achieved in a variety of ways, including the refusal to fund new projects where publication backlogs exist, and also to commission publication projects directly. A major CBRL initiative has been to commission a post-doctoral researcher to manage a post-excavation and publication project for Tel Jezreel, the last major excavation conducted by the BSAJ. This initiative, which is proving very successful, is now being repeated for other backlog projects. Publication itself is a major issue for the institutions, which publish journals, monographs, conference proceedings and newsletters on a regular basis. The collective output from the institutions is considerable, the peer-reviewed journals (Anatolian Studies, Annual of the British School at Athens, Azania, Iran, Iraq, Levant and Papers of the British School at Rome) being particularly impressive. As these are mostly related to archaeology and cognate disciplines they continue to provide an impression of archaeological strength, but do not illustrate the range of other work being conducted, generally published beyond the institutions' own outlets.

\section{Funding and Management Arrangements}

Individual Schools, Institutes and Societies are set up as distinct bodies, with their own constitutions, etc. Each has its own board of trustees, responsible to the Chari- 
ties Commission and Companies House - as well as to the major sponsors, the British Academy. Each institution has income of its own, from subscriptions, investments, donations and grants in support of specific projects from foundations and other similar bodies. This combination makes the institutions very transparent in matters of funding and management. Each institution publishes its own annual report and statement of accounts, submitted to the Charities Commission, the Academy and Companies House. Typically the boards have a small group of honorary officers, with honorary secretaries normally being recruited from UK university staff. Their considerable workload is often felt to be given insufficient value by universities and RAE panels alike. Charities Commission rules mean that trustees are not allowed to derive any personal benefit from the charity of which they are a trustee (a rule generally taken to include direct benefits, such as payments made to provide teaching support). This often also means that trustees are either not allowed to apply for research funding from the institution or are allowed to receive collectively no more than a maximum figure as agreed with the Charities Commission. Such rules can make it hard to recruit suitably qualified research active trustees, especially the honorary officers (who are generally allowed to serve for only a few years), and certainly prevent the committees from becoming self-selecting groups who directly benefit from their positions. Administration in the UK is normally conducted by a UK secretary, several of whom are based in the British Academy. Those institutions with overseas establishments generally have a director and other UK research staff, in addition to local administrative staff. Salaries, pension arrangements and contracts for UK-based staff are increasingly being harmonised with the UK academic system, which makes secondment a more realistic proposition, and ensures that recruitment is attracting a high calibre of applicant.

The concern with transparency is at its greatest with research funds. The current situation is that all the institutions must operate according to their corporate plans, which provide the basic framework for their establishment and research. In addition, all institutions must produce a strategic research plan. This indicates both the areas of research that the institution intends to pursue, and how this will be achieved. In the annual application for British Academy funds, the institutions apply through the BASIS (the British Academy Board for Academy-Sponsored Institutes and Societies) committee, dividing their bids into core, outreach and research, and providing detailed budgets for each, together with detailed annual expenditure plans and reports on activities in the preceding year. The research part of the bid is subsequently combined by BASIS and forwarded to the British Academy Research Committee, who assess this and return it to BASIS. BASIS then informs the institutions regarding their Academy funds for each of the three headings. Those institutions that distribute research funds as grants then assess applications for whatever schemes they run, and award funds following procedures that are required to be closely in line with the Academy's own. Typically, grant awarding procedures require that applications be considered by panels that include members from outside the institution's membership, and that none of the panel members may apply for, or be in receipt of, funds.

An important aspect of the institutions' research funding schemes is that they should not replicate any of the Academy's schemes, nor should they be open to external (i.e. not institutional) applicants in an open competition - these applicants should apply 
directly to the Academy, which funds research in the areas the institutions operate in. It is generally considered appropriate for the institutions to fund staff research (many cannot apply to other UK grant funding schemes due to overseas residency), and to fund some of their own research projects. There is more variation regarding other schemes for research funding, but these include small travel grants (often directed at students and postgraduates to help them gain some initial experience of the region), grants for pilot studies and grants to fund research in areas the institutions have identified as their key strategic research.

These apparently rather complicated procedures are necessary, from the institutions' perspective to ensure that our funds are used most effectively and that our use of them is transparent, and from the Academy's perspective to bring all research allocations under the auspices of its Research Committee, and to disaggregate the funds spent on the institutions. Much of this is related to the Academy wishing to bring out the distinctiveness of its activities from the AHRC, and the institutions are an important aspect of this.

\section{Public and Political Relationships}

Much has been made in the past of the value of the institutions in enabling projects to be mounted in parts of the world where research can be difficult. Others have argued that this need may be past in many countries. This sort of debate is generally rather tangential to the current role of the institutions, as it is clearly possible (except where directly prohibited by permit regulations) to mount research directly from British universities. The modern institutions do not consist of forward bases and refuges for British university teams (although some continue to use them in that manner). Instead, an important role for the institutions is to provide a direct scholarly connection within the regions in which they operate. This comprises a number of distinct roles, which vary in importance from one country to another. The permanent presence of an institution is often beneficial in countries where face-to-face contact is important, and where relationships have been built up over many years. This applies both to liaison with government ministries and departments - all the more so now that many different disciplines are involved - and to establishing close contacts with university departments. The institutions also enjoy close relationships with British diplomatic missions and British Councils, maintaining important cultural links. The CBRL's Kenyon Institute in East Jerusalem, for example, has important academic links with Palestinian universities and provides library facilities for students, while the BSAI has maintained links with Iraqi archaeologists throughout the period since the first Gulf War and is now actively involved in providing training and support. The institutions' relationships with bodies in host countries are generally very good, and enable UK researchers to have access where it would otherwise be very difficult. What is more, the institutions help to make the relationship reciprocal. A common complaint about foreign projects (often levelled in particular at UK-based academics, due to typical funding and timing constraints) is that they come in, ignore local conventions, approaches and feelings, and then leave, having achieved their own goals (or not). The institutions not only help to advise UK researchers of appropriate attitudes and behaviour, but also serve as a tangible return. The libraries are open to students and researchers in the host countries, directors frequently serve in a variety of roles as requested by local authorities, and the institutions 
organise lectures, seminars, workshops, exhibitions and conferences. Foreign institutes are generally perceived as beneficial by host governments, and there tend to be clusters of them in main centres. This may be part of a government's means of selecting and guaranteeing projects, as in Greece, or as an instrument of diplomacy, as in Italy, Jordan and Syria where various government ministries take an active interest in the activities of foreign institutes. The clustering of institutes also produces an important role in information exchange.

Institutions also develop important relationships with local scholars, both those within the various bodies mentioned above and those involved in joint projects. These provide crucial connections, and there are few substantial projects initiated now that do not represent a partnership between the UK and the host country. In addition, many of the institutions now employ local researchers. Funded by British public money, such employment tends to be for graduates of UK universities - ideally people with a longterm commitment or relationship with the British academic establishment. This is an important constituency, with whom long-term links and connections are built.

The conferences, both regional and in the UK, that the institutions organise (normally jointly with universities or government departments, both abroad and in the UK) also represent a very important connection. These can act in many different ways, bringing together researchers in the normal manner, acting as showcases for UK research, and in particular helping provide access for local students and academics to an international community of research, sometimes bridging political divisions.

\section{The Future}

The processes described above, of review, assessment and transparency, have all helped to encourage a highly competitive research atmosphere within the institutions. All are extremely active, and very much placed at the heart of British academia with many close connections to UK universities, serving wide communities. It appears inevitable that as time goes by the relationship with archaeology will increasingly become one of many, but to date the support for other disciplines has been conducted in a context where there is more archaeological research being conducted than ever before. There are, as in the UK, far fewer large-scale excavations than there once were, but the new projects are frequently exciting in terms of the techniques adopted - including remote sensing, increasingly sophisticated joint research on climate and environmental change, multi-disciplinary ventures such as the anthropological component of work at Çatalhöyük (cf. papers in Hodder 2000), use of GIS, and microstratigraphic analysis (e.g. Finlayson et al. 2003) - and operate within the same theoretical frameworks as archaeology in the UK. Other new initiatives already being developed include wider regional initiatives, such as those instigated by the British Mediterranean Schools. There have always been collaborations with institutions of other nationalities, of which there are many, some of which operate on a far larger and better funded scale than the British. Over recent years, collaboration within EU research in the region has increased, helped by EU initiatives designed to bring the countries around the Mediterranean together. This is very visible in the eastern Mediterranean, outside the EU, where there are numerous EU-funded projects, mostly related to Cultural Resource Management (CRM) and tourism, but including archaeological training. 
The Wilson report concluded that no new Schools or Institutes might be established, although the Society model might be followed. Interestingly, no new Societies have been established since then, although the Schools and Institutes have all improved their geographical coverage, with CBRL providing greater support throughout the Levant, the BSR maintaining a stronger research interest in the western Mediterranean, the BSA developing important resources (especially in its library) for the Balkans, and the BIAA launching a major new initiative around the Black Sea. In many ways, the institutions not only provide centres for UK-based research to be conducted efficiently and economically abroad, but they also help to provide an international context for that work, with strong local connections and multi-national links. They are highly active research institutions in their own right, but the role they play in facilitating both UKbased research and contact and collaboration with local researchers is enormous.

\section{Acknowledgements}

I would like to thank my colleagues in the British Mediterranean Institutes and within the CBRL who provided me with comments on an early draft of this article.

\section{References}

Barker, G. W., Adams, R., Creighton, O. H., Daly, P., Finlayson, B., Kuijt, I., Arpin, T., Chesson, M., DenGilbertson, D. D., Grattan, J. P., Hunt, C. O., Mattingley, D. J., McLaren, S. J., Newson, P., Palmer, C., Pyatt, F. B., Reynolds, T. E. G., Smith, H., Tomber, R., Truscott, A. J. 2000. Archaeology and Desertification in the Wadi Faynan: The Fourth (1999) Season of the Wadi Faynan Landscape Survey. Levant 32, $27-52$. nis, S., Goodale, N., Kadowaki, S., Maher, L., Smith, S., Schurr, M. and McKay, J. 2003. Dhra Excavation Project 2002, Interim Report. Levant 35, 1-38.

Gibson, S. 1999. British Archaeological Institutions in Mandatory Palestine, 1917-1948. Palestine Exploration Quarterly 131, 115-143.

BIAA 2005. British Institute at Ankara Website. [http://www.biaa.ac.uk] [Accessed April 2005]

BIPS 2005. British Institute of Persian Studies Website. [http://www.bips.ac.uk] [Accessed April 2005].

Hodder, I. (ed.) 2000. Towards Reflexive Method in Archaeology: The Example at Çatalhöyük. McDonald Institute for Archaeological Research/British Institute of Archaeology at Ankara Monograph 28. Cambridge: McDonald Institute for Archaeological Research.

British Academy 2005. British Academy Website. [http://www.britac.ac.uk/institutes/ index.html] [Accessed April 2005].

McQuitty, A. 1998. The Wadi Faynan Project: A Preface. Levant 30, 1-3.

Mithen, S, Finlayson, B., Pirie, A., Carruthers, D. and Kennedy, A. 2000. WF16: New Evidence for Economic and Technological Diversity in the PPNA. Current Anthropology 41, 655-662.

BSAI 2005. British School of Archaeology in Iraq Website. [http://www.britac. Patterson, H. (ed.) 2004. Bridging the Tiber: Apac.uk/institutes/iraq/newhistory.htm] proaches to Regional Archaeology in [Accessed April 2005]. the Middle Tiber Valley. Archaeological Monograph of the British School at Rome 13. London: British School at

BSR 2005. British School at Rome Website. [http:// www.bsr.ac.uk] [Accessed April 2005] Rome.

EES 2005. Egypt Exploration Society Website. Wilson, D. M. 1996. The British Schools and Insti[http://www.ees.ac.uk/home/home.htm] [Accessed April 2005]. tutes Overseas and Sponsored Societies. London: The British Academy. 